\title{
BATIK "SENG" KABUPATEN MALANG BERPEWARNA ALAMI LIMBAH KOPI SEBAGAI INOVASI PENJAGA TRADISI
}

\author{
Solikan \\ SMP Ngajum, Kabupaten Malang \\ email: wongseni69@gmail.com
}

\begin{abstract}
ABSTRAK
Batik merupakan salah satu warisan budaya Indonesia yang sangat tinggi nilainya, yang keberadaannya terus dilestarikan oleh masyarakat pendukungnya. Sebagai bagian dari kearifan lokal (local wisdom/local genius), batik juga menjadi hal yang penting bagi apa yang diistilahkan sebagai konstruksi identitas atau jati diri kebudayaan sebuah bangsa. Adapun salah satu jenis batik yang mendapatkan sambutan yang cukup tinggi di masyarakat, adalah batik dengan pewarnaan alami yang berasal dari bahan pewarna tumbuh-tumbuhan baik, dari kulit, batang, daun, bunga, maupun juga buahnya. Dimensi signfikansi perihal batik warna alami ini, terutama dikaitkan dengan faktor keamanan dan kesehatan manusia dan lingkungan alam, jika dibandingkan dengan yang berpewarna sintetik karena berasal dari bahan kimiawi. Perihal penggunaan warna alami tersebut, sebagaimana di antaranya yang ada pada batik Seng (istilah "Seng" merupakan singkatan dari Sengguruh, nama sebuah desa) di Kabupaten Malang, yakni dengan menggunakan pewarna alami dari limbah ampas kopi. Penggunaan pewarna alami dari limbah kopi tersebut, selain sebagai sebentuk pemanfaatn limbah, juga dari sisi kualitas warna yang dihasilkan cukup baik, yakni coklat keabu-abuan. Keberadaan batik "Seng" di Kabupaten Malang dengan pewarna alami dari limbah kopi tersebut, kiranya cukup ikonik dan menarik untuk dikaji.Terkait dengan hal tersebut, artikel ini bertujuan untuk mendeskripsikan tentang pemanfaatan limbah kopi sebagai bahan pewarna alami batik Seng di Kabupaten Malang, terutama dalam perspektif sebagai salah satu inovasi kreatif untuk menjaga eksistensi batik, sebagai salah satu kearifan lokal dan warisan tradisi.
\end{abstract}

Kata Kunci: Batik Seng, Pewarna Alami Kopi, Kabupaten Malang, Tradisi

\section{PENDAHULUAN}

Membahas tentang batik sesungguhnya adalah juga mengkaji tentang salah satu warisan yang mahal dalam kebudayaan kita, terutama terkait dengan apa yang dinamakan dengan kearifan lokal (local wisdom). Dalam Kamus Inggris Indonesia karya Echols \& Syadily (2012), local berarti setempat, sedangkan 
wisdom (kearifan) bisa dimaknai sebagai kebijaksanaan. Oleh karena itu, secara umum, maka local wisdom (kearifan lokal/setempat) dapat dipahami sebagai gagasan-gagasan setempat yang bersifat bijaksana, penuh kearifan, bernilai baik, yang tertanam dan diikuti oleh anggota masyarakatnya. Dari pemahaman tersebut, betapa dalam perspektif kultural, kearifan lokal amat penting keberadaannya, terutama ketika dikaitkan dengan persoalan mengenai identitas yang membentuk sebuah kesadaran negara-bangsa (Kasiyan, 2000).

Sebagai salah satu kearifan lokal dan sekaligus penanda identitas nasional, keberadaan batik bahkan diakui oleh dunia internasional. Pada tahun 2009, batik berhasil diakui sebagai warisan pusaka milik sah bangsa Indonesia, yakni oleh UNESCO (United Nations Educational, Scientific, and Cultural Organization) PBB yang dimasukkan dalam "Daftar Representatif Karya Agung Budaya Lisan dan Tak Benda Warisan Manusia" (Masterpieces of the Oral and Intangible Heritage of Humanity), yang mengalahkan banyak khazanah kain bermotif dari Malaysia, Jepang, Tiongkok, India, Afrika, Jerman, dan bahkan Belanda. Konon keunikan dan sekaligus menjadi keunggulan batik Indonesia ada pada proses, ritual, dan motif yang khusus serta sulit diduplikasi oleh pihak manapun (Tempo Interaktif, Rabu, 05 Agustus 2009).

Jika dilihat dari sisi historis, batik dipercaya sudah ada semenjak zaman Majapahit, dan menjadi sangat populer akhir abad XVIII atau awal abad XIX. Dalam pandangan Rouffaer (dalam Tirta, Steen, Urso, \& Alisjahbana, 1996) seni batik yang ada di Jawa itu berkembang sejak sekitar abad ke-12, yang didasarkan pada temuan adanya motif pola gringsing yang dibuat dengan canting (sebagai salah satu alat khas untuk membuat motif dengan lilin atau malam) di Kediri, Jawa Timur.

Dalam rangka sebagai bagian dari proses pemertahanan identitas kearifan lokal dan juga salah satu identitas kebanggaan nasional tersebut, tak mengherankan jika antusiasme masyarakat dalam mengembangkan batik ini demikian tinggi, tentu dengan pelbagai inovasi. Adapun salah satu inovasi yang kiranya menarik untuk mendapatkan perhatian dan juga apresiasi adalah yang 
dilakukan oleh masyarakat di Desa Sengguruh, Kecamatan Kepanjen, Kabupaten Malang, Jawa Timur. Sebagai salah satu sentra penghasil batik yang ada di wilayah Kabupaten Malang, yang populer dikenal dengan sebutan batik "Seng" (istilah "Seng" merupakan singkatan dari Sengguruh, nama sebuah desa), salah satu inovasi yang dikedepankan adalah dengan mempertahankan pemakaian pewarna alami.

Adapun pewarna alami yang dikenalkan dan dikembangkan di batik “Seng”, Kabupaten Malang adalah dengan memakai limbah dari ampas kopi. Pemakaian limbah ampas kopi sebagai pewarna batik tersebut, bisa dikatakan sebagai khazanah baru, mengingat selama ini yang lazim adalah dari berbagai tanaman yang sudah lazim, daun pohon nila (indigofera), kulit pohon soga tingi (ceriops candolleana arn), kayu tegeran (cudraina javanensis), kunyit (curcuma), akar mengkudu (morinda citrifelia), kulit soga jambal (pelthophorum ferruginum), kesumba (bixa orelana), daun jambu biji (psidium guajava) (Susanto 1973).

Berdasarkan pokok-pokok pikiran tersebut, artikel ini hendak mengedepankan tentang eksistensi batik Seng Kabupaten Malang, terutama terkait dengan pemakaian pewarna alami dari limbah ampas kopi sebagai sebuah inovasi.

\section{METODE}

Penelitian ini menggunakan tipe penelitian deskriptif dengan pendekatan kualitatif. Penelitian ini lebih menitikberatkan pada fokus pemanfaatan limbah kopi sebagai bahan pewarna alami batik Seng di Kabupaten Malang, terutama dalam perspektif sebagai salah satu inovasi kreatif untuk menjaga eksistensi batik, sebagai salah satu kearifan lokal dan warisan tradisi.

\section{HASIL DAN PEMBAHASAN}

\section{Pewarna Batik: Antara Sintetis dan Alami}


Sebagaimana diketahui, bahwa terkait dengan pewarnaan batik yang ada di masyarakat dikenal dengan dua jenis kategori. Pertama adalah pewarna sintetis atau kimiwai, misalnya dari bahan napthol, indigosol, rapid, dan lain sebagainya. Sementara yang kedua adalah kategori pewarna alami, yakni jenis pewarna yang dihasilkan terutama dari bahan tumbuhan, baik dari akar, batang, kulit kayu, daun, bunga, maupun buahnya. Pewarna alami dapat dihasilkan dari ekstrak tanaman dan buah yang mengandung pigmen (zat warna). Indonesia dengan diversity (keragaman) hayati yang tinggi, sangat potensial untuk menghasilkan pewarna alami yang limbahnya lebih ramah lingkungan.

Oleh karena itu, dalam perkembangannya di masayarakat, penggunaan warna alami pada batik mempunyai daya tarik dan sekaligus kelebihan dibandingkan dengan pewarna sintetis. Di antaranya yang mengemuka adalah terkait dengan faktor kesehatan, di mana bahan dari warna alami cenderung lebih aman jika dibandingkan dengan bahan pewarna sintetis yang sifatnya kimiwai yang bisa berdampak negatif bagi kesehatan, karena bisa menimbulkan penyakit kanker bagi kulit dan tubuh pemakainya.

Bahkan, World Batik Summit 2011 di Jakarta menghasilkan sebuah deklarasi bersama, pada point No. 5 yang menyatakan industri Batik Indonesia harus didasarkan atas perlindungan alam dan lingkungan, serta riset mengenai penyediaan bahan pewarna tradisional yang alami dalam jumlah besar penting untuk digalakkan.

\section{Keberadaan Batik Seng Berpewarna Alami: Selayang Pandang}

Batik "Seng" merupakan batik yang ada dan dikembangkan di Desa Sengguruh, Kecamatan Kepanjen, Malang, Jawa Timur. Sebagai sentra atau kampung batik, ada banyak perajin yang mengembangkan batik di sana. Auratik sebagai kampung batik, sangat kental di Sengguruh, yang di antaranya tampak dari gerbang masuk desa, juga banyak tembok atau dinding rumah warganya yang dihiasi dengan aneka macam motif batik. Hal ini sebagaimana tampak pada beberapa gambar berikut. 


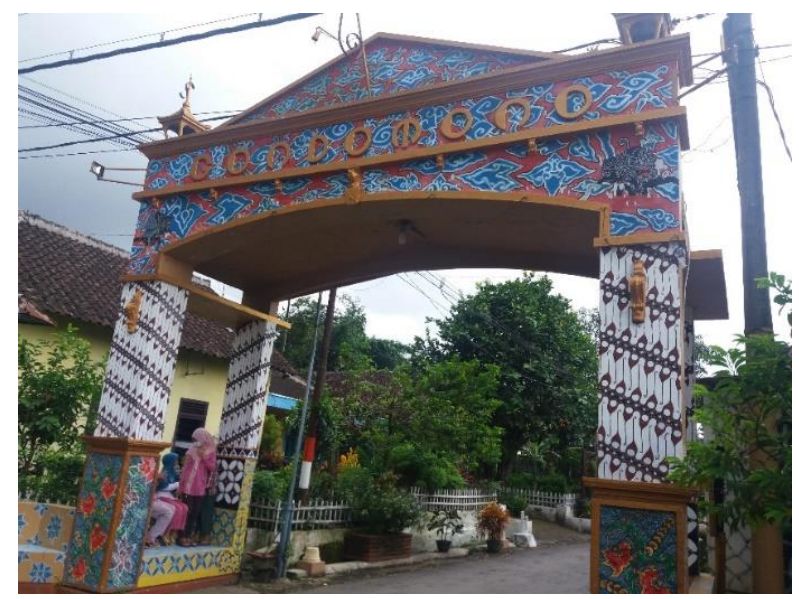

Gambar 1. Gapura Kampung Batik Seng Kabupaten Malang.

(Sumber: Solikan, 2021)
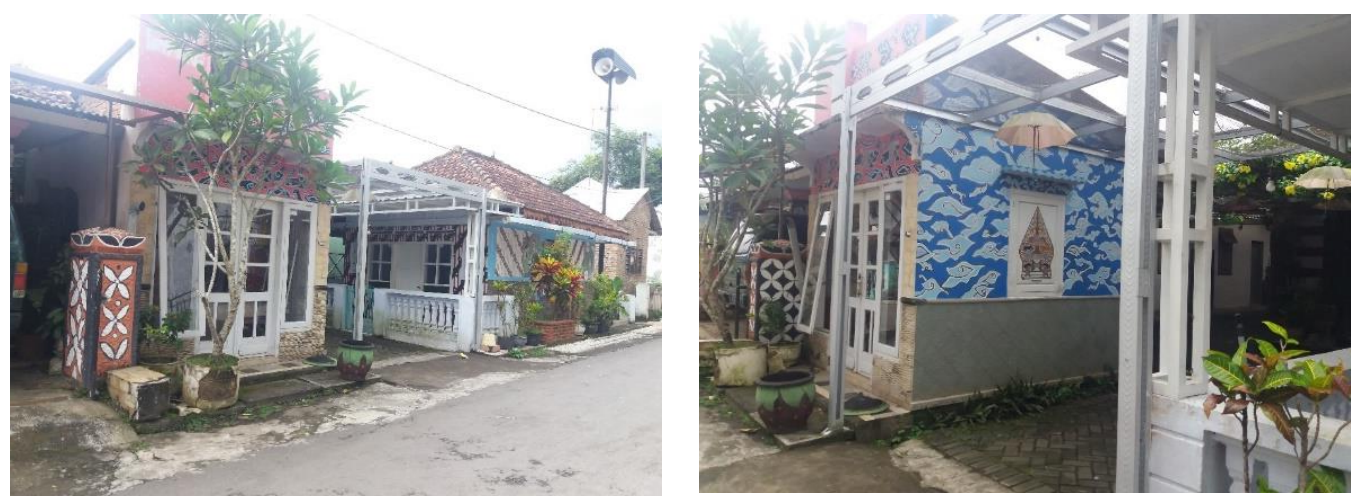

Gambar 2. Hiasan Motif Batik di Kampung Batik Seng Kabupaten Malang.

(Sumber: Solikan, 2021)

Batik "Seng” di Desa Sengguruh, Kepanjeng, kabupaten Malang ini, mulai dirintis sejak 2014 silam, dan terus berkembang sampai sekarang. Keberadaan kampung atau sentra batik Seng ini, juga berfungsi sebagai tempat untuk pelbagai kegiatan pelatihan batik yang terbuka bagi masyarakat luas, baik dari dalam maupun luar negeri. 


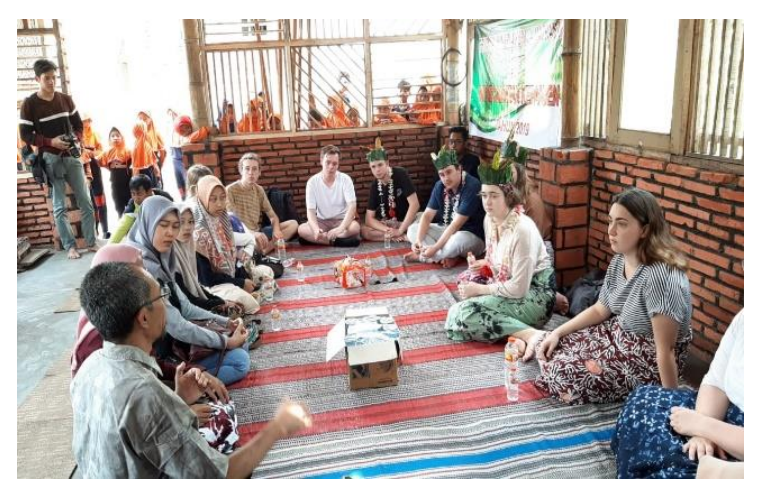

Gambar 3. Wisatawan Asing yang Berkunjung dan Belajar Batik di Batik Seng Kabupaten Malang.

(Sumber: Solikan, 2021)

Adapun produk yang dihasilkan di kampung batik "Seng" ini adalah terutama untuk keperluan sandang (baju/kemeja) dan juga kelengkapan lain misalnya tas. Terkait dengan jumlah produksi dan nilai omzetnya per bulan sebelum wabah pendemi covid 19 dapat disampaikan, mencapai sekitar 200 potong dengan nilai sekitar Rp. 40 jutaan.

\section{Limbah Kopi sebagai Bahan Pewarna Alami}

Sebagaimana disampaikan di atas, bahwa salah satu keunikan dan sekaligus keunggulan dari eksistensi batik "Seng" tersebut adalah terkait dengan pemakaian zat warna alami yang digunakan sebagai pewarna kain batiknya. Adapun zat warna alami yang dapat dikatakan relatif unik yang dipakai di batik "Seng”, yakni dari limbah ampas atau sisa minuman kopi. Di samping juga memakai pewarna alami yang lainnya, sebagaimana lazimnya yang dipakai di banyak tempat lain di Indonesia. Pewarna alami dengan bahan limbah ampas kopi tersebut, mengahasilkan warna yang cenderung coklat keabu-abuan, yang menarik dan estetis sekali.

Berdasarkan informasi dari hasil wawancara (Maret 2021) dengan salah seorang tokoh atau pengelola Batik Seng, yakni Evi Wahyu Astutik, mengaku bahwa munculnya ide bereksplorasi warna limbah kopi, berawal dari kakaknya yang jual kopi di Malang, yang limbahnya sangat banyak dan biasanya dibuang. 
Kemudian ada gagasan pemikiran untuk mencobanya, diolah untuk kemungkinan dijadikan sebagai bahan baku pewarna batik. Ternyata dari pelbagai proses eksperimen, disimpulkan bahwa bahan dari limbah ampasa kopi itu sangat baik hasilnya sebagai bahan untuk pewarna batik di sana. Warna yang dihasilkan dari bahan baku pewarna limbah ampas kopi ini adalah cenderung coklat keabu-abuan.

Sebagai antisipasi terkait dengan ketersediaan bahan baku berupa limbah ampas kopi tersebut, kemudian pihak perajin menjalin kerjasama dengan banyak warung kopi yang ada di seputaran Kecamatan Kepanjen, kabupaten Malang, sehingga relatif terjaga kesinambungan (sustainability)-nya.
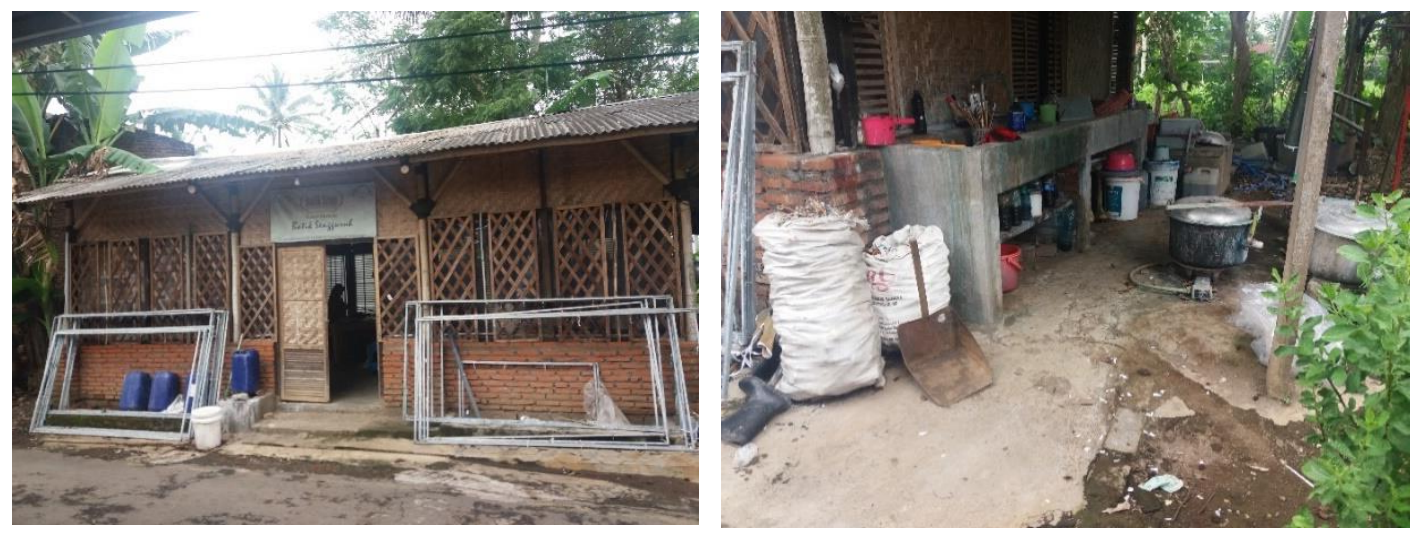

Gambar 4. Studio dan Perlengkapan Membatik Batik Seng, Kabupaten Malang.

(Sumber: Solikan, 2021)

Secara agak teknis dapat disampaikan bahwa proses pembuatan warna alam limbah kopi dengan bahan baku dari "lêthêk" (bahasa Jawa) atau "ampas" dari sisa minuman kopi di batik "Seng" tersebut, diberikan fiksasi untuk mengunci warna agar tidak mudah pudar atau luntur, atau dalam istilah lain lebih kuat dan awet. Fiksasi merupakan proses pencelupan yang bertujuan untuk mengunci zat warna yang masuk ke dalam serat agar warna yang dihasilkan tidak mudah pudar atau luntur (Thomas, dkk., 2013). Fiksasi dilakukan dengan menambahkan bahan yang mengandung kompleks logam. Bahan fiksasi yang biasa digunakan antara lain kapur, tawas, dan tunjung. Demikian juga alam konteks ini, ada 3 penguat 
warna yang dapat digunakan untuk pewarna dari limbah kopi ini, yakni dengan tawas, kapur, dan tunjung, dengan hasil warna yang berbeda, terutama dari sisi gradasinya, mulai dari tua sampai muda.

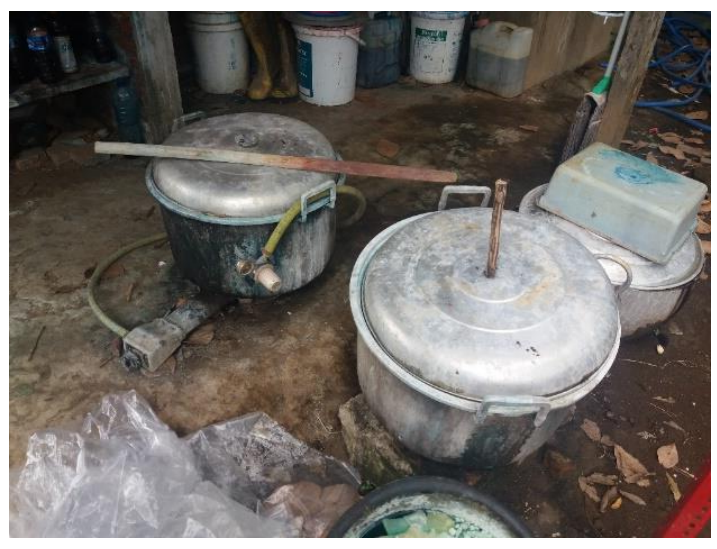

Gambar 5. Peralatan untuk Membuat Pewarna Alami dari Kopi di Kampung Batik Seng Kabupaten Malang.

(Sumber: Solikan, 2021)

Sementara itu dari sisi keteknikan, pembuatan batik di batik Seng tersebut, dengan teknik batik tulis yang dibuat dengan memakai canting dan juga dengan teknik cap.
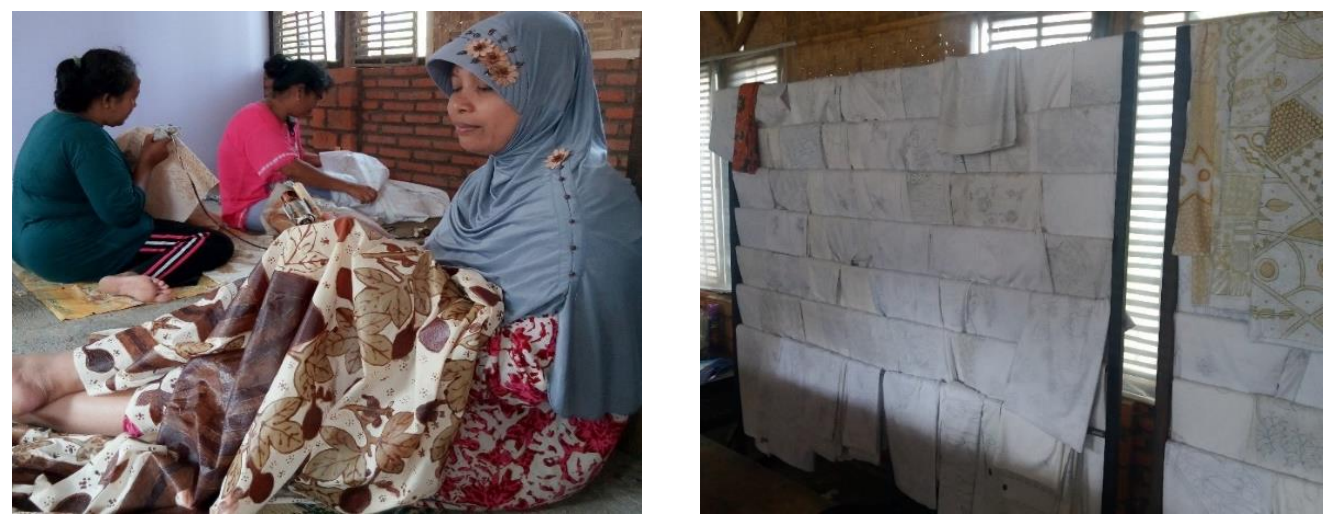

Gambar 6. Peralatan untuk Membuat Pewarna Alami dari Kopi di Kampung Batik Seng Kabupaten Malang.

(Sumber: Solikan, 2021) 
Untuk jenis motif yang khas dari Batik Sengguruh menurut pengakuan pengelola Bati Seng ini hampir sama dengan centra batik di Kabupaten Malang yakni motif yang mengangkat budaya setempat atau kearifan lokal, seperti motif topeng (kesenian khas Kedung Monggo Kabupaten Malng), Apel (Buah khas kota Batu), Pantai Balekambang (wisata khas Jalur Lintas Selatan Kabupaten Malang), ubi Gunung Kawi (salah satu ubi khas yang dihasilkan dari Gunung Kawi Kabupaten Malang) dan masih banyak lagi, yang dikembangkan bersaman dengan motif batik kontemporer lainnya.

Kemudian, jika dilihat dari jenis produknya, batik Seng di Kabupaten Malang tersebut, menghasilkan produk, yakni terutama untuk keperluan sandang (baju/kemeja) dan juga kelengkapan lain misalnya tas. Beberapa contoh produk untuk bahan sandang sebagaimana dimaksud adalah sebagai berikut.
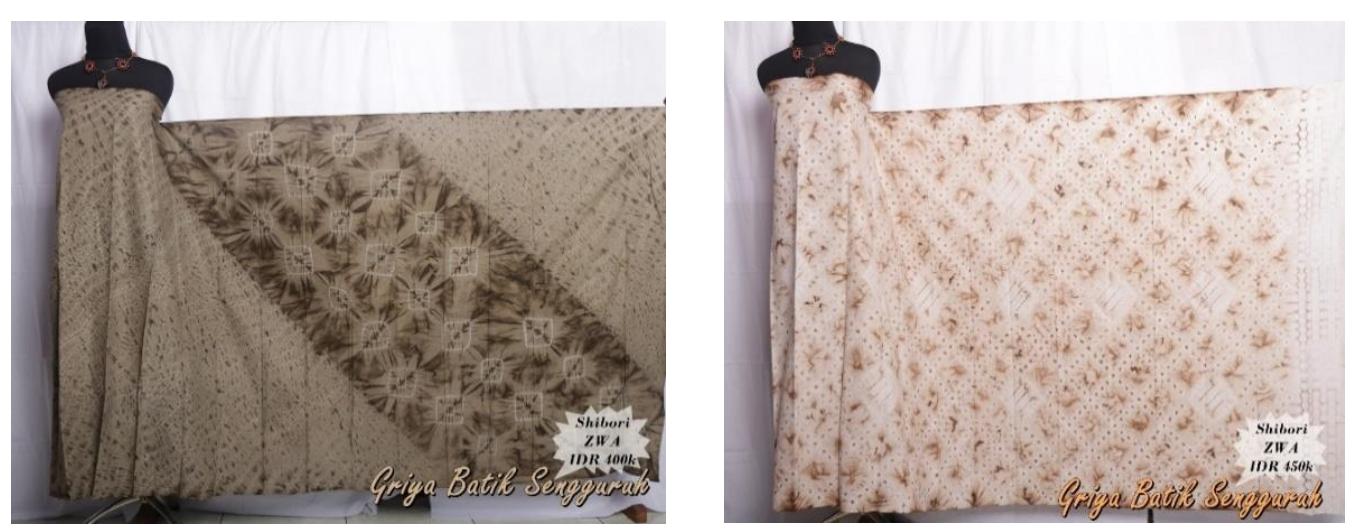

Gambar 7. Contoh Produk Sandang Batik Seng, Kabupaten Malang dengan Pewarna Alami dari Limbah Ampas Kopi.

(Sumber: Solikan, 2021)

Sementara itu, contoh produk untuk perlengkapan lain, misalnya berupa tas yang dihasilkan di Batik Seng, Kabupaten Malang dengan pewarna alami dari limbah ampas kopi yakni sebagai berikut. 

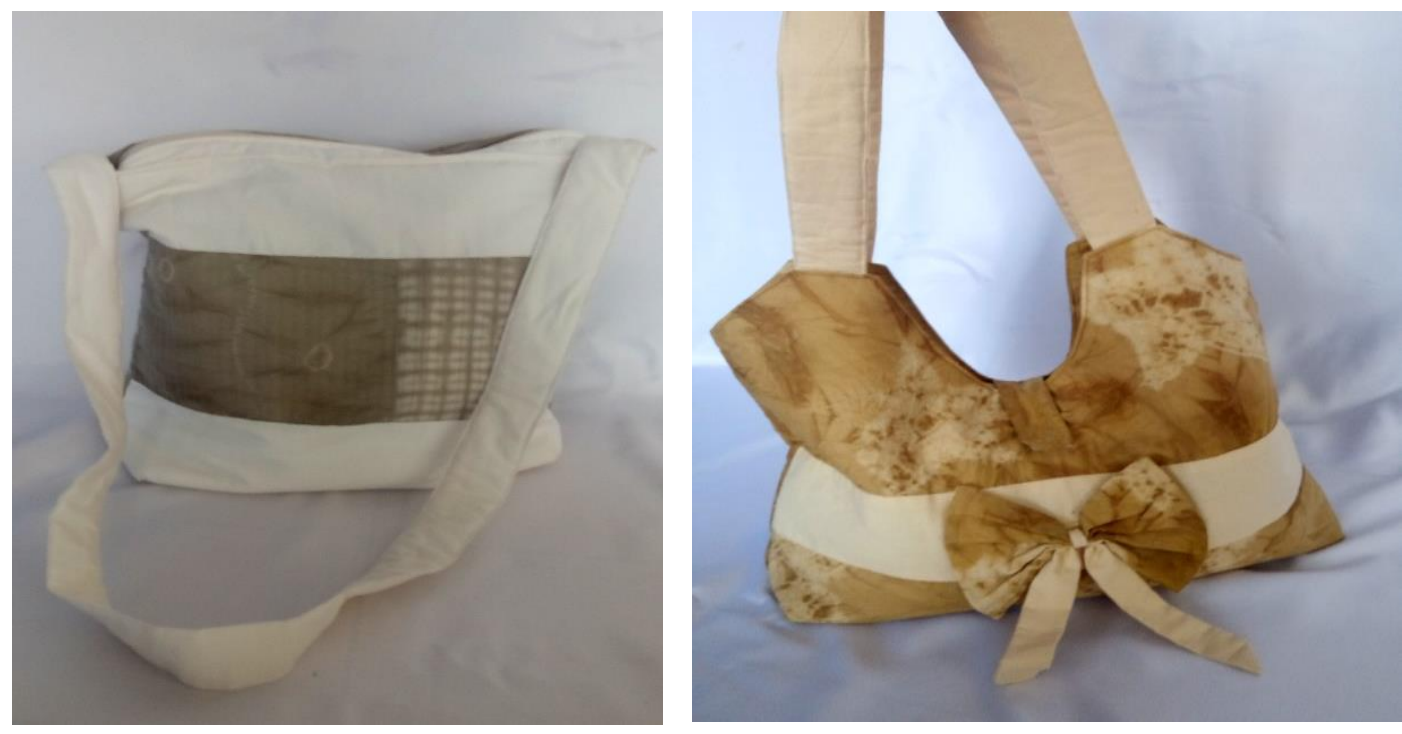

Gambar 8. Contoh Produk Tas Batik Seng, Kabupaten Malang dengan Pewarna Alami dari Limbah Ampas Kopi.

(Sumber: Solikan, 2021)

Berdasarkan sajian data-data terkait dengan penggunaan bahan baku pewarna alami dari limbah ampas kopi sebagaimana dimaksud, dapat disampaikan bahwa betapa fenomena tersebut sebagai sebentuk langkah kreatif pengembangan dan inovasi dalam menjaga, merawat, dan melestarikan batik sebagai sebagai aset tradisi. Sebagaimana disampaikan di atas, bahwa pelbagai hal yang menjadi bagian tradisi dan kebudayaan lokal, sejatinya adalah sesuatu yang mahal bagi eksistensi konstruksi jati diri dan identitas sebuah masyarakat dan bangsa tentunya.

Apalagi dalam konteks globalisasi yang terjadi di zaman modern ini, di mana pengaruh budaya asing demikian kuatnya, yang kalau tidak diantisipasi bisa menghilangkan eksistensi budaya lokal sendiri. Soebadio (dalam Ayatrohaedi, 1986) mengatakan bahwa local genius adalah juga cultural identity, identitas/kepribadian budaya bangsa yang menyebabkan bangsa tersebut mampu menyerap dan mengolah kebudayaan asing sesuai watak dan kemampuan sendiri (Ayatrohaedi, 1986). 
Kebudayaan memang harus selalu dipandang sebagai manifestasi kehidupan orang atau kelompok orang yang selalu mengubah alam. Kegiatan manusia memperlakukan lingkungan alamiahnya, itulah kebudayaan. Kebudayaan merupakan usaha manusia, perjuangan setiap orang atau kelompok dalam menentukan hari depannya. Kebudayaan merupakan aktivitas yang dapat diarahkan dan direncanakan (Peursen, 1986). Oleh sebab itu dituntut adanya kemampuan, kreativitas, dan penemuan-penemuan.

\section{SIMPULAN}

Berdasarkan beberapa pokok pikiraan terkait dengan realitas eksisitensi seni batik, sebagai salah satu warisan pusaka budaya lokal, mengandung makna, bahwa keberadaannya sebagai aset yang mahal bagi identitas dan jati diri budaya sebuah bangsa. Pelbagai uaya pelesteriannya kiranya merupakan satu hal yang akan menggaransi keberadaannya. Termasuk tentunya, pelbagai upaya yang dilakaukan oleh perajin batik "Seng" di Kabupaten Malang, dengan inovasi penggunaan pewarna alami dari limbah ampas kopi, sebagai sebentuk upaya bagi proses pelestarian demi keberlangsungan warisan tradisi batik tersebut di masa kini dan terutama masa mendatang. Karena memang, suatu kebudayaan bagaimanapun tidak dapat dilepaskan begitu saja dari ruang di mana kebudayaan itu dibangun, dipelihara, dan dilestarikan.

\section{DAFTAR PUSTAKA}

Ayatrohaedi (Ed.). 1996. Kepribadian Budaya Bangsa (Local Genius). Jakarta: Pustaka Jaya.

Echols, M. \& Syadily, H. 2012. Kamus Inggris-Indonesia. Jakarta: Gramedia.

Kasiyan. 2010. "Batik Riwayatmu Kini: Beberapa Catatan Tegangan Kontestasi”. Prosiding Seminar Nasional Revitalisasi Batik Melalui Dunia Pendidikan. Penerbit: Jurusan Pendidikan Seni Rupa Fakultas Bahasa dan Seni 
Universitas Negeri Yogyakarta. Tahun 2010. ISBN:978-602-8429-32-0. Hal. 68-88.

Peursen, V. 1986. Strategi Kebudayaan. Yogyakarta: Kanisius.

Unesco Putuskan Batik Tulis Indonesia sebagai Pusaka Dunia, Tempo Interaktif, Rabu, 05 Agustus 2009.

Thomas, M., Manuntun, M., I. A. Raka, \&Astiti, A. 2013. "Pemanfaatan Zat Warna Alam dai Ekstrak Kulit Akar Mengkudu (Morinda citrifolia Linn) pada Kain Katun. Jurnal Kimia, 7 (2): 119-126.

Tirta, I, Steen, G.L, Urso, D.M., \& Alisjahbana, M. 1996. Batik: A Play of Lights and Shades. Volume 1. Jakarta: Gaya Favorit Press.

Susanto, S. 1973. Seni Kerajinan Batik Indonesia. Yogayakarta: BPKB 